\title{
PREVALENCE OF HERPES SIMPLEX VIRUS TYPE 2 AND RISK FACTORS ASSOCIATED WITH THIS INFECTION IN WOMEN IN SOUTHERN BRAZIL
}

\author{
Thaís Duquia Moraes CALDEIRA, Carla Vitola GONCCALVES, Gisele Rodrigues de OLIVEIRA, Tânia Vieira da FONSECA, \\ Regina GONÇALVES, Clair Teixeira do AMARAL, Vanusa Pousada da HORA \& Ana Maria Barral de MARTINEZ
}

\begin{abstract}
SUMMARY
The herpes simplex virus type 2 (HVS-2) is the most prevalent infection worldwide. It is a cofactor in the acquisition of human immunodeficiency virus (HIV) and the persistence of human papillomavirus (HPV). This study evaluated the prevalence of HSV-2, using the polymerase chain reaction (PCR), and associated factors in patients treated at the Federal University of Rio Grande (FURG) and Basic Health Units (BHU) in Rio Grande, Brazil. The observed prevalence of HSV-2 was 15.6\%. Among the 302 women studied, 158 had received assistance in BHU and 144 were treated at FURG. The prevalence of HSV-2 in these groups was $10.8 \%$ and $20.8 \%$, respectively, RR 1.9 and $p=0.012$. Knowledge about the Pap smear, and the presence of lesions showed no association with HSV-2 infection. Multivariate analysis showed that the variable that most influenced the risk of HSV-2 infection was the presence of HIV infection, with a relative risk of 1.9 and $p=0.04$. Discussion: Genital ulcers are an important entry point for HIV, and condom use is an important strategy to reduce transmission of HIV and HSV-2.
\end{abstract}

KEYWORDS: Human Herpesvirus 2; Polymerase Chain Reaction; Human Papillomavirus; HIV Infections.

\section{INTRODUCTION}

Lesions caused by the herpes virus were first documented by Hippocrates (460-377 B.C.E.), who called them "herpes," a word derived from reptiles, as a reference to the formation of skin vesicles. The herpes simplex virus (HSV) is a DNA virus that belongs to the family Herpesviridae. There are two types of HSV: HSV-1, associated with non-genital infections, and HSV-2, which causes lesions below the waist, especially in the genital area ${ }^{23}$. However, some studies suggest that the prevalence of HSV-1 in genital lesions has not only increased in recent years, but may even exceed that of $\mathrm{HSV}-2^{23}$.

HSV-2 is one of the most prevalent infections in the world. It is estimated that, in the United States, 40-60 million people are infected, with an incidence of 1-2 million infections and 600,000-800,000 new cases per year $^{29}$. The latest HSV-2 data published by the Centers for Disease Control and Prevention (CDC) at the National Sexually Transmitted Diseases Conference in 2010 in Atlanta indicated that the prevalence of HSV-2 is still high (16.2\%), especially among black women, where rates may be as high as $48 \%$. Global prevalence is higher in women compared to men, especially among young people ${ }^{8}$. GARNETT et al. $(2004)^{14}$ concluded that there is a six times greater chance of herpes transmission from men to women compared with transmission from women to men. In developed countries, where the acquisition of HSV-1 in childhood has been reduced,
HSV-2 seroprevalence has increased, suggesting a possible protective effect of HSV-1 against acquisition of HSV-2 ${ }^{29}$. In Brazil, 640,000 new cases of genital herpes are diagnosed annually ${ }^{20}$.

From 1960 to 1970 , HSV-2 infection was considered a possible causative agent of cervical cancer ${ }^{1,11,12,24,27}$. The role of HSV-2 in the development of cervical cancer has been questioned, since HSV-2 DNA was not found in cervical cancer biopsies ${ }^{12}$. However, women with HSV-2 have a higher risk of developing cervical carcinoma, and therefore HSV-2 is considered as a cofactor in certain patients ${ }^{1,7,27}$. In vitro laboratory data and molecular evidence show a possible synergism between HPV and HSV-2 in cervical-cancer etiology ${ }^{1}$.

In addition, symptomatic or asymptomatic herpetic infections can facilitate the acquisition of human immunodeficiency virus (HIV $)^{15}$. The presence of herpes lesions indicates a two-to-three-fold higher risk of HIV transmission ${ }^{3,14,16}$. Therefore, primary prevention of HSV-2 infection may be the best available strategy for reducing the risk of infection by HIV ${ }^{9}$.

Since herpes simplex virus type 2 (HSV-2) is one of the most prevalent infections in the world, and is a cofactor in HIV acquisition and in the persistence of human papillomavirus (HPV), this study assessed HSV-2 prevalence using the polymerase chain reaction (PCR) technique, as well as the factors associated with its infection. 


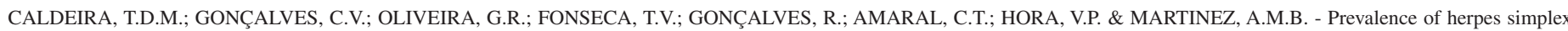
virus type 2 and risk factors associated with this infection in women in Southern Brazil. Rev. Inst. Med. Trop. Sao Paulo, 55(5): 315-21, 2013.

\section{MATERIALS AND METHODS}

This project was approved by the Ethics Committee in Health Area Research - CEPAS/FURG, no. 19/2010, CEPAS 67/2010; and by the Municipal Center of Health Permanent Education (NEPES), no. 013/2011.

Sample size was calculated using Epi-info $6.04^{\circledR}$ software. A $95 \%$ confidence level was used, with an estimated HSV-2 prevalence between 12 and $39 \%$ (mean $25 \%)^{19}$. A total of 288 women and a sample error of $5 \%$ were obtained. Samples of cervicovaginal secretions of the women included in the study were collected by the gynecologist during a gynecological examination, with the use of a VAGISPEC ${ }^{\circledR}$ brush, for further molecular analysis and Pap smear. Patients participating in the study sought by the average service complaints gynecological, obstetric or just to collect the pap smear samples. There was no patient in this group with complaints or symptoms of genital ulcer at the time of the examination.

For the molecular analysis, samples were stored in cryogenic tubes containing Tris-EDTA (TE) buffer $(10 \mathrm{mM}$ Tris- $\mathrm{HCl} \mathrm{pH} 8.5 ; 1 \mathrm{mM}$ EDTA) and sent to the Molecular Biology Laboratory of the School of Medicine (FAMED) at the Federal University of Rio Grande (FURG), until the extraction of viral DNA. A Pap smear was evaluated as a routine procedure at the Pathology Laboratory (FAMED, FURG) and the results were later compared to the molecular biology results for HSV-2 and HPV viruses.

DNA was extracted from the samples with the commercial kit GFX (GE Healthcare) ${ }^{\circledR}$ GenomicBlood DNA Purification Kit, according to the protocol for blood cell extraction.

HSV-2 was detected by two PCR reactions in a nested configuration (nested-PCR), adapted to AURELIUS ${ }^{4}$ and SCHMUTZHARD ${ }^{26}$ protocols. First-round amplification of the gene encoding the HSV2 viral capsid glycoprotein ( $\mathrm{gp}$ ) was performed using the primers HSV21F 5' TCAGCCCATCCTCCTTCGGCAGTA 3' and HSV21R 5' GATCTGGTACTCGAATGTCTCCG 3', generating a 184 bp fragment; and HSV22F 5' AGACGTGCGGGTCGTACACG 3' and HSV22R 5' CGCGCGGTCCCAGATCGGCA 3' primers, amplifying to $100 \mathrm{bp}$. Consecutive PCR reactions were performed using $6 \mu \mathrm{L}$ of the extracted DNA and $4 \mu \mathrm{L}$ of the first PCR product, respectively, $1 \mathrm{x}$ PCR buffer, $2 \mathrm{mM} \mathrm{MgCl}, 0.5 \mathrm{mMdNTP}, 1 \mathrm{U}$ of the recombinant enzyme Taq DNA polymerase (Invitrogen) and $0.5 \mu \mathrm{M}$ of HSV21F, HSV21R, HSV22F, HSV22R, and $\mathrm{H}_{2} \mathrm{O}$ Milli-Q QSP primers. Both reactions were performed in a final volume of $50 \mu \mathrm{L}$. Reaction cycles were performed in a thermocycler (Biorad-MyCycler). Reaction conditions for the first and second rounds were the same, represented by an initial stage at 94 ${ }^{\circ} \mathrm{C}$ for five min for DNA denaturation and 30 subsequent amplification cycles at $94{ }^{\circ} \mathrm{C}$ for $30 \mathrm{~s}$ for denaturation, $57^{\circ} \mathrm{C}$ for $30 \mathrm{~s}$ for annealing, $72{ }^{\circ} \mathrm{C}$ for one min for primer extension, and a final stage at $72{ }^{\circ} \mathrm{C}$ for seven min. Based on electrophoresis, the molecules spin through the gel and the results obtained from the molecular techniques are shown. Amplicon was observed in 2.5\% agarose gel for the second round in a UV transilluminator after staining in ethidium bromide $(0.5 \mu \mathrm{g} / \mathrm{mL})$ for 30 min. The image was photographed using Kodak EDAS software (Kodak 1D Image Analysis 3.5). Size was compared using the molecular weight marker Leidwing Biotec ${ }^{\circledR}$ Ladder 50 bp Puls. A positive and a negative cervical sample for HSV-2 were used as reaction controls, in addition to a blank reaction omitting any DNA (Fig. 1).

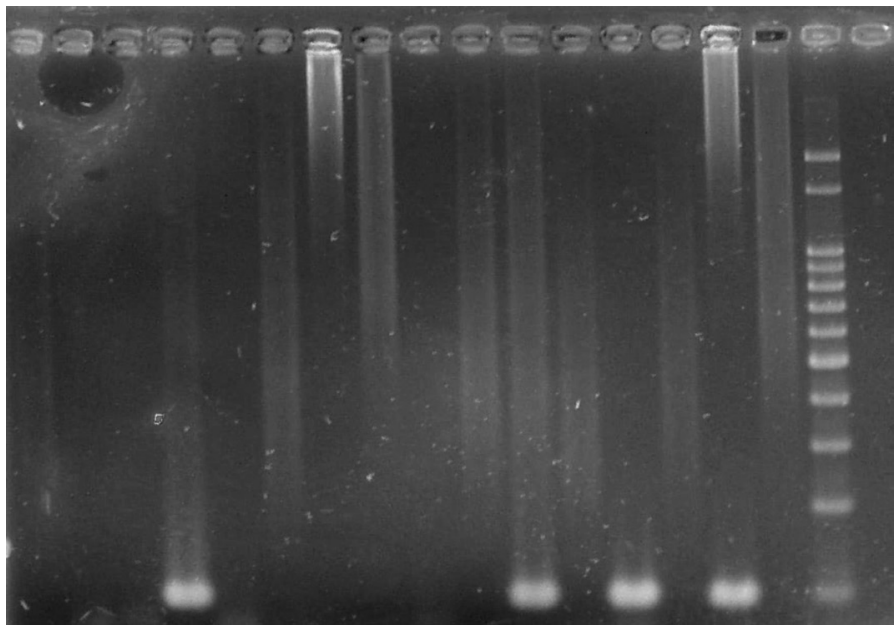

Fig. 1 - Result of PCR reaction, performed by Thais D. M. Boiler Laboratory of Molecular Biology - FAMED / FURG - on 05.10.2011. Negative samples: 1, 2, 3, 5, 6, 7, 8, 10, 12, 14, 16. Positive samples: 4, 11, 15. Negative Control: 9. Positive Control: 13. Blank (no DNA): 18. Bookmark Leidwing Biotec ${ }^{\circledR}: 17$.

For HPV detection, nested PCR was performed. The first round was carried out with external primers: M Y 0 9/M Y 1 1: 5' C G T C C M A A R G G AWA C T G AT C 3', 5'GCMCAGGGWCATAAYAATGG3' ${ }^{18}$, which amplifies a 450 bp fragment of the L1 viral capsid. The second round was held with the internal primers: GP5 / 6: 5'TTTGTTACTCTGGTAGATAC3 'and 5'GAAAAATAAACTGTAAATCA3 “28 amplifying a fragment of 150 $\mathrm{bp}$, also of the L1. Both reactions were performed in a final volume of $50 \mu \mathrm{L}$, containing $2.5 \mathrm{U}$ of Taq DNA polymerase, $25 \mathrm{pmol} / \mu \mathrm{L}$ of each primer at a concentration of $1.5 \mathrm{mM} \mathrm{MgCl}, 200 \mu \mathrm{M}$ of each dNTP and Milli-Q $\mathrm{H}_{2} \mathrm{O}$ QSP. For the first round, $3 \mu \mathrm{L}$ of extracted DNA was used; and for the second round, a $5 \mu \mathrm{L}$ aliquot of the product was used. The reaction conditions for the first round consisted of 40 repeated cycles of $94{ }^{\circ} \mathrm{C}$ for $30 \mathrm{~s}$ for denaturation, $45^{\circ} \mathrm{C}$ for $30 \mathrm{~s}$ for annealing, $72{ }^{\circ} \mathrm{C}$ for $30 \mathrm{~s}$ for extension; and for the second round, 40 repeated cycles of $95^{\circ} \mathrm{C}$ for one $\mathrm{min}, 55^{\circ} \mathrm{C}$ for one $\min$ and $72{ }^{\circ} \mathrm{C}$ for one min for denaturation, annealing and extension, respectively. The amplicon was visualized on $1 \%$ and $2 \%$ agarose gel respectively in the first and second round transilluminator (UV), by a system photodocumentation EDAs Kodak (B) after being plated with ethidium bromide solution $(10 \mathrm{mg} / \mathrm{mL})$. The size was compared with the molecular weight marker Leidwing Biotc ${ }^{\circledR}$ Puls 50 bp ladder. As a positive control reaction, a positive sample was used (a fragment of the viral genome of $450 \mathrm{bp}$ ) and a negative control with omission of any DNA.

Statistical analyses were performed using SPSS software, predicting crude analysis, calculation of prevalence ratio, confidence intervals, and $p$ value, considering that differences were statistically significant when $p<0.05$ and using Fisher's exact test or chi-square. The main variables under analysis were: sociodemographic (skin color, age, education, income, marital status), gynecological (age at first sexual encounter, lifetime number of sexual partners, number of sexual partners in the past six months, contraceptive method, previous STD infection, number of 


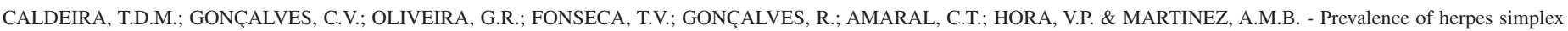
virus type 2 and risk factors associated with this infection in women in Southern Brazil. Rev. Inst. Med. Trop. Sao Paulo, 55(5): 315-21, 2013.

pregnancies, number of deliveries, and knowledge of STDs) and clinical and laboratory data, such as Pap smear results. Data on plasma viral load and T CD4+ lymphocytes in HIV-positive patients were obtained by analysis of medical charts. Multivariate analysis was performed in the SPSS software using Poisson regression, followed by a hierarchic analysis model in which variables with $p=0.20$ were integrated into the crude analysis. The first level included demographic and socioeconomic variables. The second level included variables that represented risk factors for HSV infection.

\section{RESULTS}

Of the 302 patients included in the study, 47 (15.6\%) had an HSV-2 infection. Mean age was 32.7 years, standard deviation (SD) of 13.6, and mean family income of $\mathrm{R} \$ 1,400$, with $88.1 \%$ earning one minimum salary or more. Table 1 shows that the only demographic variable significantly associated with HSV-2 was education level; patients with less than four years of school had a higher prevalence of infection compared to patients with more than nine years of school $(p=.232)$.

As to the gynecological history, $71.5 \%$ of the patients had their first sexual encounter at a mean age of 17 years or less. The mean number of total sexual partners was five, and $86.7 \%$ reported having one partner over the past six months. The obstetric history showed that $62.9 \%$ had had two or more pregnancies, and $49.7 \%$ had two or more deliveries (Table 2).
Table 2 also shows that $18.6 \%$ of women reported using contraceptive methods. However, contraceptive use showed no statistically significant association with prevention of HSV-2 infection. STDs were reported by $23.3 \%$ of the patients, and this group was more likely to have an HSV-2 infection $(p=.053)$.

For the Pap smear, 276 (91.4\%) patients had normal results, 12 (4\%) had a low to moderate degree of intraepithelial changes, and for $14(4.6 \%)$ the results of the Pap smear could not be located. Knowledge of Pap smear and the presence of lesions in this examination were not correlated with a higher risk of HSV-2 infection (Table 2).

Of the 302 patients, 158 had been seen at Basic Health Units (BHU) and 144 at UH-FURG outpatient clinics. HSV-2 prevalence in these groups was $10.8 \%$ and $20.8 \%$, respectively. There was a significant difference in HSV prevalence between recruiting locations, with confidence interval $\left.{ }_{95 \%} \mathrm{CI}\right): 1.12-3.36$ and $p=.012$. There was a significant difference between HIV-positive and HIV-negative women. HIV-positive women were more likely to be infected by HSV-2 ( $p=.001)$. However, neither viral load nor the CD4 count of HIV-infected women was correlated with this infection by HSV-2 (Table 2).

Multivariate analysis showed that the only variable correlated with a risk of HSV-2 infection was the presence of HIV, with ${ }_{95 \%} \mathrm{CI}$ : 1.42-6.33 and $p=.04$ (Table 3).

Table 1

Description of the sample and prevalence of herpes virus type 2, and physical and economic risk factors associated with the infection in women in southern Brazil

\begin{tabular}{|c|c|c|c|c|c|}
\hline Variables/Category & $\mathrm{n}(\%)$ & $\mathrm{HSV}+\mathrm{n}(\%)$ & Prevalence ratio & $\mathrm{CI}_{95 \%}$ & $p$ \\
\hline \multicolumn{6}{|l|}{ Age } \\
\hline$\leq 20$ years & $62(21.2)$ & $6(9.4)$ & 1.0 & & $p=0.232^{\mathrm{b}}$ \\
\hline 21-30 years & $104(34.4)$ & $17(16.3)$ & 1.7 & $0.73-4.19$ & \\
\hline $31-40$ years & $57(18.9)$ & $13(22.8)$ & 2.4 & $0.99-5.98$ & \\
\hline$\geq 41$ years & $77(25.5)$ & $11(14.3)$ & 1.5 & $0.60-3.89$ & \\
\hline \multicolumn{6}{|l|}{ Skin color } \\
\hline White & $202(66.9)$ & $31(15.3)$ & 1.0 & & $p=0.503^{\mathrm{a}}$ \\
\hline Non-white & $100(33.1)$ & $16(16.0)$ & 1.0 & $0.60-1.81$ & \\
\hline \multicolumn{6}{|l|}{ Marital status } \\
\hline With partner & $198(65.6)$ & $27(13.6)$ & 1.0 & & $p=0.135^{\mathrm{a}}$ \\
\hline Without partner & $104(34.4)$ & $20(19.2)$ & 1.4 & $0.83-2.39$ & \\
\hline \multicolumn{6}{|l|}{ Education } \\
\hline 9 years or more & $55(19.4)$ & $6(10.9)$ & 1.0 & & $p=0.032^{\mathrm{b}}$ \\
\hline $5-8$ years & $68(24)$ & $5(7.4)$ & 0.7 & $0.22-2.09$ & \\
\hline 4 years or less & $160(56.5)$ & $32(20)$ & 1.8 & $0.81-4.15$ & \\
\hline \multicolumn{6}{|l|}{ Income $^{c}$} \\
\hline 2 or more minimum salaries & 109 (41.9) & $18(16.5)$ & 1.0 & & $p=0.871^{\mathrm{b}}$ \\
\hline 1-1.9 minimum salaries & $120(46.2)$ & $20(16.7)$ & 1.0 & $0.56-1.81$ & \\
\hline Under 1 minimum salary & $31(11.9)$ & $4(12.9)$ & 0.8 & $0.29-2.14$ & \\
\hline \multicolumn{6}{|l|}{ Smoker } \\
\hline No & $234(77.5)$ & $34(14.5)$ & 1.0 & $0.84-2.35$ & $p=0.230^{\mathrm{a}}$ \\
\hline Yes & $68(22.5)$ & $13(19.1)$ & 1.3 & & \\
\hline
\end{tabular}

${ }^{\mathrm{a}}$ Fisher's exact test; ${ }^{\mathrm{b}} \mathrm{Chi}$-square test; ${ }^{\mathrm{C}}$ Minimum salary at the time of the study: R\$539.00. 
CALDEIRA, T.D.M.; GONÇALVES, C.V.; OLIVEIRA, G.R.; FONSECA, T.V.; GONÇALVES, R.; AMARAL, C.T.; HORA, V.P. \& MARTINEZ, A.M.B. - Prevalence of herpes simplex virus type 2 and risk factors associated with this infection in women in Southern Brazil. Rev. Inst. Med. Trop. Sao Paulo, 55(5): 315-21, 2013.

Table 2

Description of the sample and prevalence of herpes virus type 2, and clinical and gynecological risk factors associated with the infection in women in southern Brazil

Variables/Category

Age at first sexual encounter

$$
\begin{aligned}
& \geq 18 \text { years } \\
& \leq 17 \text { years }
\end{aligned}
$$

\section{Lifetime number of partners}

1 partner

2-4 partners

5 partners or more

No. of partners over the past 6 months

None

1 partner

2 partners or more

Number of pregnancies

Nulligravida

Primigravida

Secundigravida

Multigravida

\section{Number of deliveries}

Nulliparous

Primiparous

Multiparous

Uses condom

Yes

No

\section{Contraceptive method}

Condom

Hormonal contraceptive

None

Other methods

\section{Had STD before}

$$
\text { No }
$$

Yes

\section{Knows about herpes}

Yes

No

Knows about STD (HSV, Chlamydia, HPV)

$$
\begin{aligned}
& \text { Yes } \\
& \text { No }
\end{aligned}
$$

Previous knowledge about Pap smear

Yes

No

Had Pap smear before

Yes

No

$\mathrm{n}(\%)$

$86(28.5)$

$14(16.3)$

33 (15.3)

85 (28.2)

129 (42.9)

11 (12.9)

19 (14.7)

87 (28.9)

$16(18.4)$

20 (6.6)

261(86.7)

$20(6.6)$

3 (15)

39 (14.9)

5 (25)

38 (12.6)

74 (24.5)

8 (21.1)

9 (12.12)

$71(23.5)$

8 (11.3)

$119(39.4)$

22 (18.5)

$81(26.8)$
$71(23.5)$

150 (49.7)

92 (30.5)

210 (69.5)

59 (19.5)

153 (50.7)

48 (15.9)

42 (13.9)

$242(80.1)$

60 (19.9)

167 (55.3)

135 (44.7)

200 (66.2)

$102(33.8)$

278 (92.1)

24 (7.9)

$241(79.8)$

$61(20.2)$
$12(14.8)$

12 (16.9)

$22(15.3)$

17 (18.5)

30 (14.3)

11 (18.6)

23 (15)

8 (16.7)

5 (11.9)

33 (13.6)

14 (23.3)

30 (18.0)

17 (12.6)

33 (16.5)

14 (13.7)

45 (16.2)

$2(8.3)$

38 (15.8)

9 (14.8)
1.0

0.9

1.0

1.1

1.4

1.0

1.0

1.7

1.0

0.6

0.5

0.9

1.0

1.1

1.0

1.0

0.8

1.0

0.8

0.9

0.6

1.0

1.7

1.0

0.7

1.0

0.8

1.0

0.5

1.0

0.9
$\mathrm{CI}_{95 \%}$

$p^{\mathrm{a}}$

$p=0.477^{\mathrm{a}}$

$0.53-1.66$

$p=0.595^{\mathrm{b}}$

$0.57-2.27$

$0.70-2.88$

$p=0.489^{\mathrm{b}}$

$0.34-2.94$

$0.46-6.06$

$p=0.348^{\mathrm{b}}$

$0.24-1.38$

$0.22-1.31$

$0.43-1.81$

$p=0.934^{\mathrm{b}}$

$0.55-2.38$

$0.54-1.97$

$p=0.224^{\mathrm{a}}$

$0.45-1.33$

$p=0.818^{\mathrm{b}}$

$0.41-1.55$

$0.39-2.04$

$0.24-1.70$

$p=0.053^{\mathrm{a}}$

$0.98-2.99$

$p=0.131^{\text {a }}$

$0.40-1.22$

$p=0.326^{\mathrm{a}}$

$p=0.244^{\mathrm{a}}$

$0.13-1.99$

$p=0.512^{\mathrm{a}}$

$0.48-1.83$ 


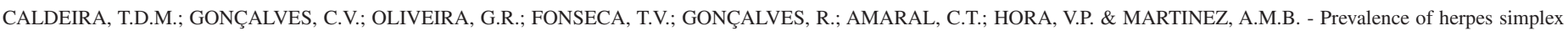
virus type 2 and risk factors associated with this infection in women in Southern Brazil. Rev. Inst. Med. Trop. Sao Paulo, 55(5): 315-21, 2013.

Table 2

Description of the sample and prevalence of herpes virus type 2, and clinical and gynecological risk factors associated with the infection in women in southern Brazil (cont.)

\begin{tabular}{|c|c|c|c|c|c|}
\hline Variables/Category & $\mathrm{n}(\%)$ & $\mathrm{HSV}+\mathrm{n}(\%)$ & Prevalence ratio & $\mathrm{CI}_{95 \%}$ & $p^{\mathrm{a}}$ \\
\hline \multicolumn{6}{|l|}{ Pap smear } \\
\hline Normal & $276(91.4)$ & $41(15.1)$ & 1.0 & & $p=0.279^{\mathrm{a}}$ \\
\hline Altered & $12(4)$ & $3(25)$ & 1.7 & $0.60-4.60$ & \\
\hline \multicolumn{6}{|l|}{ Sample unit origin } \\
\hline UBS & $158(52.3)$ & $17(10.8)$ & 1.0 & & $p=0.012^{\mathrm{a}}$ \\
\hline $\mathrm{HU}$ & $144(47.7)$ & $30(20.8)$ & 1.9 & $1.12-3.36$ & \\
\hline \multicolumn{6}{|l|}{ Patient category } \\
\hline Pregnant & $96(31.8)$ & $10(10.4)$ & 1.0 & & $p=0.011^{\mathrm{b}}$ \\
\hline HIV pregnant & $24(7.9)$ & $8(33.3)$ & 6.4 & $3.34-12.28$ & \\
\hline Gynecological & $162(53.6)$ & $23(14.2)$ & 1.4 & $0.68-2.74$ & \\
\hline HIV gynecological & $20(6.6)$ & $6(30)$ & 2.9 & $1.18-7.01$ & \\
\hline \multicolumn{6}{|l|}{ Has HIV } \\
\hline No & $258(85.4)$ & $33(12.8)$ & 1.0 & & $p=0.001^{\mathrm{b}}$ \\
\hline Yes & $44(14.6)$ & $14(31.8)$ & 2.5 & $1.45-4.26$ & \\
\hline \multicolumn{6}{|l|}{ CD4 } \\
\hline Equal or lower than 249 & $15(37.5)$ & $5(33.3)$ & 1.0 & $0.42-2.60$ & $p=0.599^{\mathrm{a}}$ \\
\hline Higher than 350 & $25(62.5)$ & $8(32.0)$ & 1.0 & & \\
\hline \multicolumn{6}{|l|}{ Viral load } \\
\hline Undetectable VL & $17(42.5)$ & $7(41.2)$ & 1.0 & & $p=0.252^{\mathrm{a}}$ \\
\hline With VL & $23(57.5)$ & $6(26.1)$ & 0.6 & $0.26-1.55$ & \\
\hline \multicolumn{6}{|l|}{ Has DNA HPV } \\
\hline No & $247(81.8)$ & $39(15.8)$ & 1.0 & & $p=0.502^{\mathrm{a}}$ \\
\hline Yes & $55(18.2)$ & $8(14.5)$ & 0.9 & $0.46-1.86$ & \\
\hline
\end{tabular}

${ }^{\mathrm{a} F i s h e r ' s ~ e x a c t ~ t e s t ; ~}{ }^{\mathrm{b}}$ Chi-square test.

Table 3

Multivariate analysis of risk factors associated with HSV-2 infection in women in southern Brazil

\begin{tabular}{lccc}
\hline $\begin{array}{l}\text { Variables/ } \\
\text { Category }\end{array}$ & $\begin{array}{c}\text { Prevalence } \\
\text { ratio }\end{array}$ & $\mathrm{CI}_{95 \%}$ & $p^{\mathrm{a}}$ \\
\hline Age & 1.0 & & \\
$\quad \leq 20$ years & 1.1 & $0.20-1.70$ & \\
$\quad$ 21-30 years & 1 & $0.43-2.35$ & \\
$\quad$ 31-40 years & 1.5 & $0.65-3.42$ & \\
$\quad$ 41 years & & & \\
Unit & 1.0 & & \\
$\quad$ UBS & 1.76 & $0.82-3.76$ & \\
HU & & & \\
Has HIV & 1.0 & & \\
No & 3.0 & $1.42-6.33$ & \\
Yes & & &
\end{tabular}

\section{DISCUSSION}

The prevalence of HSV-2 found in this study using the PCR technique was $15.6 \%$. A literature review on data for the prevalence of HSV-2 using PCR in Brazil found no earlier publications. However, similar data can be found in the international literature, showing that the incidence of HSV-2 is still high. A study of women from Gambia, West Africa, found an HSV-2 infection rate of $15 \%{ }^{2}$. Similar data were reported by the CDC at the National STD Conference in 2010, showing an HSV-2 prevalence of $16.2 \%$, a rate that can reach up to $48 \%$ in black women. In a study of pregnant women conducted at Washington University, HSV-2 DNA was detected in 207 of the 716 women included, with a $28.9 \%$ rate and 25.7 to $32.3 \%$ standard deviation ${ }^{13}$. However, in a study performed in six cities in the USA on endocervical secretion, HSV-2 DNA was found in $7 \%$ of the samples ${ }^{3}$. Although this finding is lower than others reported in the literature, this study might have used a different population sampling or DNA extraction technique.

Among demographic variables, only education, with four or fewer years of school was associated with HSV-2 acquisition $(p=.032)$, suggesting that patients with less education have little knowledge of the means of transmission and identification of lesions. Other studies showed that black and Hispanic women, lower education level, and low per capita family income are risk factors for HSV-2 infection?'. Patient 
CALDEIRA, T.D.M.; GONÇALVES, C.V.; OLIVEIRA, G.R.; FONSECA, T.V.; GONÇALVES, R.; AMARAL, C.T.; HORA, V.P. \& MARTINEZ, A.M.B. - Prevalence of herpes simplex virus type 2 and risk factors associated with this infection in women in Southern Brazil. Rev. Inst. Med. Trop. Sao Paulo, 55(5): 315-21, 2013.

skin-color difference was not significant in our study.

Many risk factors have been described in HSV-2 acquisition. Among them are early sexual relations, previous history of STDs, and multiple sexual partners ${ }^{8,9,20,29}$. In the present study, patients who reported having had any STDs were more likely to have HSV-2 infection ( $p=$ .053). In terms of STDs, there was a $31.8 \%$ HSV-2 DNA prevalence in HIV-positive women, whereas the rate found in the group of HIVnegative women was $12.8 \%(p=.001)$. A study using the molecular biology technique to detect HSV-2 in HIV-positive women showed a $37 \%$ prevalence rate of this infection in this group ${ }^{10}$. A study using a seroepidemiological survey of HSV-2 performed in Brazil on $100 \mathrm{HIV}$ positive patients showed a prevalence rate of $73 \%$ in this population ${ }^{17}$.

In addition to a higher HSV-2 prevalence found in HIV-positive women, there was also a high rate of HIV-positive pregnant women with herpetic infections (33.3\%). According to BROWN et al. $(2003)^{6}$, viral excretion is the strongest risk factor for HSV transmission from the mother to the newborn at birth. A study conducted by PATTERSON et al. (2011) 22 showed that pregnant women co-infected with HSV-2/ HIV are more likely to transmit HSV at birth than are HIV-negative pregnant women. This finding draws attention to a little-studied situation in Brazil, namely, the risk of vertical transmission of HSV-2 in asymptomatic HIV-positive pregnant women. Therefore, women infected by HSV-2 should be tested for HIV and adopt prevention strategies, such as using a condom.

Several studies have associated HSV-2 infection with a higher risk of developing cervical carcinoma, and HSV-2 infection has been considered a cofactor of this disease $\mathrm{e}^{1,11,12,24,27}$. Molecular evidence shows a possible synergism between HPV and HSV-2 in the etiology of cervical cancer; HSV-2 infection could support the persistence of HPV infection, increasing the risk of cervical lesions caused by this virus ${ }^{1}$. The results of this study showed that $95.8 \%$ of the patients had a normal Pap smear and only $4.2 \%$ had a low- to high-degree intraepithelial lesion. HSV-2 prevalence was $15.1 \%$ in women with normal Pap smear and $25 \%$ in women with altered Pap smear. Although the herpetic infection rate was higher in the second group, it was not associated with a significant risk of acquiring this infection. In addition, when HSV-2 prevalence was assessed in relation to HPV, women with HPV had an HSV-2 rate of $14.5 \%$, whereas in the HPV-negative group the rate was $15.8 \%$. Therefore, this study found no association between HSV/HPV co-infection nor a higher risk of intraepithelial lesions in the HSV-2-positive group.

Another hypothesis investigated in this study was the possibility of a higher herpetic infection rate among women seen in a tertiary health center (UH-FURG) in relation to women seen in a primary center (BHU). HSV-2 prevalence among UH women was $20.8 \%$, whereas it was $10.8 \%$ at BHUs. Therefore, women seen at the tertiary health center showed a higher risk of being HSV-2-positive $(p=.012)$. This finding suggests that the population seen at the UH has behavioral, clinical and/ or gynecological characteristics that differ from the population seen at the BHUs, showing that the former group requires more attention, follow-up and information regarding STDs.

In this study, we observed that HIV-positive patients had a higher prevalence of infection with HSV-2. Therefore, the herpes infection can be a gateway to HIV, and conversely, HIV can be a risk factor for acquisition of herpes ${ }^{14,16,17,22,25}$. Although no study patient had a genital ulcer present at the time of collection, they could have had these injuries at some point in their lives. STD presence increases the risk of HIV infection, especially when genital ulcers are present ${ }^{8,9,20,29}$. In addition, herpetic infection is more recurrent, more extensive, and has more serious symptoms in HIV-positive patients, and may also influence the clinical worsening of these patients. Thus, more attention should be given to herpetic infection in HIV-positive patients. It is extremely important to prevent such infections using awareness campaigns, such as education regarding use of a condom and risk behaviors for virus acquisition, and more attention from health professionals in patients with typical lesions or recurrent genital symptoms. An HSV2 diagnosis should be requested, preventing future virus transmission and controlling both infections.

\section{RESUMO}

\section{Prevalência do herpes vírus tipo 2 e fatores de risco associados a sua infecção em mulheres do sul do Brasil}

O vírus herpes simplex tipo 2 (HVS-2) é uma das infecções mais prevalentes em todo o mundo. Considera-se um co-factor na aquisição do vírus da imunodeficiência humana (HIV) e na persistência do papilomavirus humano (HPV). Este estudo tem como objetivo avaliar a prevalência de HSV-2 usando a reação em cadeia da polimerase (PCR) e fatores associados em pacientes atendidos na Universidade Federal do Rio Grande e em Unidades Básicas de Saúde (UBS) do Rio Grande, Brasil. A prevalência de HSV-2 encontrada neste estudo foi de 15,6\%. Entre as 302 mulheres estudadas, 158 haviam recebido assistência na UBS e 144 foram atendidos na FURG. A prevalência de HSV-2 nestes grupos foi de 10,8 e $20,8 \%$, respectivamente, com RR: 1,9 e $p=0,012$. Conhecer o exame de Papanicolaou, e presença de lesão não teve associação com infecção HSV-2. A análise multivariada mostrou que a variável que influencia no risco de infecção HSV-2 foi o paciente ter HIV, com risco relativo 1,9 e $p=0,04$. Discussão: As úlceras genitais são importante porta de entrada para o vírus HIV e o uso do preservativo é estratégia importante para reduzir a transmissão do HIV e do HSV-2.

\section{ACKNOWLEDGMENTS}

To the Obstetrics and Gynecological Service at the Teaching Hospital (UH-FURG) and to the Basic Health Units for permission to conduct this study.

\section{REFERENCES}

1. Al-Daraji WI, Smith JH. Infection and cervical neoplasia: facts and fiction. Int J Clin Exp Pathol. 2009;2:48-64.

2. Aryee EAN, Bailey RL, Natividad-Sancho A, Kaye S, Holland MJ. Detection, quantification and genotyping of Herpes Simplex Virus in cervicovaginal secretions by real-time PCR: a cross sectional survey. Virol J. 2005;2:61.

3. Aumakhan B, Hardick A, Quinn TC, Laeyendencker O, Gange SJ, Beyrer C, et al Genital herpes evaluation by quantitative TaqMan PCR: correlating single detection and quantity of HSV-2 DNA in cervicovaginal lavage fluids with cross-sectional and longitudinal clinical data. Virol J. 2010;7:328.

4. Aurelius E, Johansson B, Skoldenberg B, Staland A, Forsgren M. Rapid diagnosis of herpes simplex encephalitis by nested polymerase chain reaction assay of cerebrospinal fluid. Lancet. 1991;337:189-92. 
CALDEIRA, T.D.M.; GONÇALVES, C.V.; OLIVEIRA, G.R.; FONSECA, T.V.; GONÇALVES, R.; AMARAL, C.T.; HORA, V.P. \& MARTINEZ, A.M.B. - Prevalence of herpes simplex virus type 2 and risk factors associated with this infection in women in Southern Brazil. Rev. Inst. Med. Trop. Sao Paulo, 55(5): 315-21, 2013.

5. Barnabas RV, Celum C. Infectious co-factors in HIV-1 transmission herpes simplex virus type-2 and HIV-1: new insights and interventions. Curr HIV Res. 2012;10:228-37.

6. Brown ZA, Wald A, Morrow A, Selke S, Zeh J, Corey L. Effect of serologic status and cesarean delivery on transmission rates of herpes simplex virus from mother to infant. JAMA. 2003;289:203-9.

7. Celum C, Wald A, Hughes J, Sanchez J, Reid S, Delany-Moretlwe S, et al. Effect of aciclovir on HIV-1 acquisition in herpes simplex virus type 2 seropositive women and men who have sex with men: a randomized, double blind, placebo-controlled trial. Lancet. 2008;371(9630):2109-19.

8. Centers for Disease Control and Prevention (CDC). Analysis of National Herpes Prevalence. 22 April 2010. [Cited 2012 May 26]. Available from: <http:// www.cdc.gov/std/Herpes/herpes-NHANES-2010.htm>

9. Centers for Disease Control and Prevention (CDC). Seroprevalence of herpes simplex virus type 2 among persons aged 14-49 years - United States, 2005-2008. MMWR Morb Mortal Wkly Rep. 2010;59(15):456-9.

10. Clemens SA, Farhat CK. Soroprevalência de anticorpos contra vírus herpes simples 1-2 no Brasil. Rev Saúde Pública. 2010;44:726-34.

11. Farivar TN, Johari P, Shafei S, Najafipour R. Lack of association between herpes simplex virus type 2 infection and cervical cancer--Taq Man realtime PCR assay findings. Asian Pac J Cancer Prev. 2012;13:339-42.

12. Galloway DA, McDougall JK. The oncogenic potential of herpes simplex viruses: evidence for a 'hit-and-run' mechanism. Nature. 1983;302:21-4.

13. Gardella C, Huang ML, Wald A, Margaret A, Selke S, Morrow R, et al. Rapid polymerase chain reaction assay to detect herpes simplex virus in the genital tract of women in labor. Obstet Gynecol. 2010;115:1209-16.

14. Garnett GP, Dubin G, Slaoui M, Darcis T. The potential epidemiological impact of a genital herpes vaccine for women. Sex Transm Infect. 2004;80:24-9.

15. Glasier A, Gülmezoglu M, Schmid GP, Moreno CG, Van Look PF. Sexual and reproductive health: a matter of life and death. Lancet. 2006;368(9547):1595-607.

16. Homans J, Christensen S, Stiller T, Wang CH, Mack W, Anastos K, et al. Permissive and protective factors associated with presence, level, and longitudinal pattern of cervicovaginal HIV shedding. J Acquir Immune Defic Synd. 2012;60:99-110.

17. Le Goff J, Weiss HA, Gresenguet G, Nzambi K, Frost E, Hayes RJ, et al. Cervicovaginal HIV-1 and herpes simplex virus type 2 shedding during genital ulcer disease episodes. Aids. 2007;21:1569-78.

18. Manos MM, Ting Y, Wright DK, Lewis AI, Broker TR, Wolinsky SM. The use of polymerase chain reaction amplification for the detection of genital human papillomaviruses. Cancer Cells. 1989;7:209-14.
19. Mertz GJ, Rosenthal SL, Stanberry LR. Is herpes simplex virus type 1 (HSV-1) now more common than HSV-2 in first episodes of genital herpes? Sex Transm Dis. 2003;30:801-2

20. Ministério da Saúde. Brasil. Doenças infecciosas e parasitárias / Guia de bolso. $8^{\mathrm{a}}$ ed. Brasília-DF; 2010. 444 p.

21. Nagot N, Ouedraogo A, Konate I, Weiss HA, Foulongne V, Defer MC, et al. Roles of clinical and subclinical reactivated herpes simplex virus type 2 infection and human immunodeficiency virus type 1 (HIV-1)-induced immunosuppression on genital and plasma HIV-1 levels. J Infect Dis. 2008;198:241-9.

22. Patterson J, Hitti J, Selke S, Huang ML, Watts DH, Brown Z, et al. Genital HSV detection among HIV-1-Infected pregnant women in labor. Inf Dis Obstet Gynecol. 2011;2011:1-4. (Article ID 157680).

23. Pereira VS, Moizeis RN, Fernandes TA, Araújo JM, Meissner RV, Fernandes JV. Herpes simplex virus type 1 is the main cause of genital herpes in women of Natal, Brazil Eur J Obstet Gynecol Reprod Biol. 2012;161:190-3.

24. Rawls WE, Tompkins WA, Figueroa ME, Melnick JL. Herpesvirus type 2: association with carcinoma of the cervix. Science. 1968;161(3847):1255-6.

25. Reinheimer C, Doerr HW. Prevalence of herpes simplex virus type 2 in different risk groups: thirty years after the onset of HIV. Intervirology. 2012;55:395-400.

26. Schmutzhard J, Merete Riedel H, Zweygberg Wirgart B, Grillne L. Detection of herpes simplex virus type 1 , herpes simplex virus type 2 and varicella-zoster virus in skin lesions. Comparison of real-time PCR, nested PCR and virus isolation. J Clin Virol 2004;29:120-6.

27. Smith JS, Herrero R, Bosetti C, Muñoz N, Bosch FX, Eluf-Neto J, et al. Herpes simplex virus-2 as a human papillomavirus cofactor in the etiology of invasive cervical cancer. J Natl Cancer Inst. 2002;94:1604-13.

28. Van Den Brule AJC, Snijders PJF, Gordijn RLJ, Bleker OP, Meijer CJLM, Walboomers JMM. General primer-mediated polymerase chain reaction permits the detection of sequenced and still unsequenced human papillomavirus genotypes in cervical scrapes and carcinomas. Int J Cancer. 1990;45:644-9.

29. WHO. World Health Organization 2010. Sexually transmitted diseases - herpes simplex type 2. [Cited 2012 May20]. Available from: <http://www.who.int/vaccine_research/ diseases/soa_std/en/index3.html>

Received: 11 June 2012

Accepted: 5 February 2013 